Fisheries Science

March 2018, Volume 84 Issue 2 Pages 283-292

http://dx.doi.org/10.1007/s12562-017-1173-2

http://archimer.ifremer.fr/doc/00429/54019/

(C) Japanese Society of Fisheries Science 2018

\title{
Application of the coastal ecosystem complex concept toward integrated management for sustainable coastal fisheries under oligotrophication
}

\author{
Hori Masakazu ${ }^{1,{ }^{*}}$, Hamaoka Hideki ${ }^{1}$, Hirota Masahito ${ }^{2}$, Lagarde Franck ${ }^{3}$, Vaz Sandrine ${ }^{3}$, \\ Hamaguchi Masami ${ }^{1}$, Hori Juri ${ }^{2}$, Makino Mitsutaku ${ }^{2}$
}

${ }^{1}$ Japan Fisheries Res \& Educ Agcy, Natl Res Inst Fisheries, Environm Inland Sea, 2-17-5 Maruishi, Hiroshima 7390452, Japan.

2 Japan Fisheries Res \& Educ Agcy, Natl Res Inst Fisheries Sci, Yokohama, Kanagawa, Japan.

${ }^{3}$ Ifremer UMR MARBEC, F-34200 Sete, France.

*Corresponding author : Masakazu Hori, email address : mhori@affrc.go.jp

\begin{abstract}
:
Harmonizing coastal fisheries with water-quality improvement has become an essential factor for the sustainable use of coastal ecosystem services. Here, we present the scope of our study based on an interdisciplinary approach including ecological actions, socio-economic actions and socio-psychological actions. We chose to focus on the interaction between oyster aquaculture and seagrass vegetation as a typical ecological action using the coastal ecosystem complex (CEC) concept. Coastal organisms have adapted their traits to the environment over a long period of time, so that restoration of the CEC represents reconstruction of the original process of coastal production. Subtidal seagrass vegetation with intertidal oyster reefs is the original CEC in Japan, which would be expected to enhance coastal production by improving the production efficiency without adding nutrients. A simple field experiment examining carbon and nitrogen contents and stable isotope ratios revealed that oyster spats cultivated on a tidal flat adjacent to seagrass beds had higher nitrogen contents and higher $\delta 13 \mathrm{C}$ ratios than spats cultivated in an offshore area using only pelagic production. This result suggests that utilization of the CEC, which enables oysters to use both pelagic and benthic production, has potential to sustain a food provisioning service for humans, even in oligotrophic conditions.
\end{abstract}

Keywords: Oyster aquaculture, Seagrass, Indigenous and local knowledge, Integrated coastal management 
Through evolution, organisms have interacted with their inhabiting environments and have changed various traits as adaptations to the environment (Sensu Niche construction; Odling-smee et al. 2003). Coastal zone is an ecotone between terrestrial and marine ecosystems forming a mosaic of seascapes characterized by various habitats such as rocky shores, seagrass meadows, coral reefs, mangrove forests and tidal flats (Pittman et al. 2011), which is called Coastal Ecosystem Complex (hereafter as CEC) here. Coastal organisms also have interacted with these habitats and adapted their traits to the environment over a long period of time since before humans began development in coastal zones, meaning that coastal organisms would originally possess some traits to effectively utilize the CEC for their growth and reproduction. However, it is well-known that various kinds of coastal developments due to humans have altered and decreased these habitats and the connectivity, especially from the Industrial Revolution in the eighteenth centuryn. Therefore, the restoration of original multiple habitats and the connectivity would potentially lead to the recovery of the original state of biological production promoted by effective utilization of those multiple habitats. The restoration of the CEC represents a reconstruction to the original process of coastal production.

52 At the same time, the marine coastal area is one of the most important ecosystem providing a wide 53 variety of ecosystem services for the human community. It has been suggested that $23 \%$ of the world 54 human population live within a $100 \mathrm{~km}$ distance of the coast line (about three times higher than the global average of the human population density ; IPCC 2007) and utilize these ecosystem services, suggesting

56 that coastal ecosystems have been exposed to the influence of over-use and pollution caused by human 57 activities in both coastal terrestrial and marine areas, such as urbanization, agricultural development and industrial development, leading to eutrophication. Actually coastal environments of the world have been influenced by artificial eutrophication with environmental pollution such as red tide blooms and hypoxia 

caused the excessive pelagic production in coastal areas, which has caused serious decline of other important coastal production of benthic ecosystems (Hori and Tarutani 2015) as well as lake ecosystems (Scheffer et al. 2001).

Recently as public awareness of coastal pollution has become higher, the quality of coastal waters has been gradually and successfully improved in some regions by the decrease of nutrient concentrations, namely oligotrophication (Matsuda 2015). Oligotrophication generally improves water quality, in particular water transparency, by decreasing excessive pelagic phytoplankton production (Scheffer et al. 2001). The higher transparency due to oligotrophication has led to the recovery of various important ecosystem functioning and services in coastal areas, especially derived from benthic primary production including seagrass vegetation (Burkholder et al. 2007; Hori and Tarutani 2015). Seagrass beds have been suggested as one of the most important coastal vegetation for climate change mitigation and adaptation, such as blue carbon storage and protection from sea-level rise and storm surges, as well as food provision and security (Arkema et al. 2013; Duarte et al. 2013). These ecosystem services are generally welcomed by environmentally aware stakeholders, in particular by several world-wide international organizations such as IPCC, UNFCCC, UNEP, FAO and IPBES (Hori and Kuwae 2017). These organizations aim to make some ocean agenda related to national/international climate change initiatives for climate mitigation and adaptation, which include effective conservation and restoration of the coastal vegetation.

However, some coastal stakeholders have suggested that the improvement of water quality with oligotrophication is now causing another issue in coastal ecosystem services (Collos et al. 2009;

80 Yamamoto and Hanazato 2015). Oligotrophication has reduced pelagic productivity in coastal ecosystems, sometimes resulting in the decline of the fishery catch and the harvest of seaweed and bivalve aquaculture

82 (Yamamoto and Hanazato 2015; Yanagi 2015). This is presumably because of the following reasons. 
adaptation to the eutrophication of coastal waters over periods of multiple decades. For example in the Seto Inland Sea, Japan, most of the recent fishery catch is dependent on pelagic production, while before the 1960s, when eutrophication had not yet occurred, the most dominant fish catch was for other species contingent on benthic production (Tsurita et al. 2017). Second, eutrophication generally increases pelagic productivity and, due to the lower transparency by increasingly dense phytoplankton, a decrease in the benthic productivity occurs. The eutrophication has caused fishermen to change from coastal fishing to seaweed or bivalve aquaculture using the enriched nutrients and abundant phytoplankton, due to its stable benefits of eutrophication (Tsurita et al. 2017). Therefore their recently targeted resources for exploitation cannot be obtained without an environment affected by eutrophication. Third, oligotrophication decreases the total amount of nutrients in coastal areas from a high to a low level, indicating the possibility that the total coastal productivity including both pelagic and benthic biological production itself decreases with oligotrophication. Therefore, the integrated coastal ecosystem management harmonizing coastal fishery with water-quality improvement is now essential for a sustainable and wise use of coastal ecosystem services.

Here, we have adopted the CEC concept as a key option of our integrated coastal management to create a better balance between sustainable coastal fishery and continuous water-quality improvement under oligotrophication, in order to ensure both future food security and climate change mitigation. The adoption of the CEC concept would be expected to enhance coastal productivity by improving the production efficiency even while undergoing oligotrophication. The Thau lagoon and the Seto Inland Sea, located in southern France and western Japan, respectively, are our study sites and are well-known as typical coastal areas undergoing oligotrophication (Collos et al. 2009 ; Yanagi 2015). It is suggested that the DIN has been reduced to about $40 \%$ of that in the 1980's in the Seto Inland Sea, and that the soluble reactive phosphorus concentration decreased from 10 micro $\mathrm{M}$ to 1 micro $\mathrm{M}$ in the summer period in the Thau Lagoon. In both study sites, the aquaculture of Pacific oyster Crassostrea gigas is an economically important fishery for the human community, and eelgrass, Zostera marina, whoserecovery by 
water-quality improvement is also now apparent. The combination of subtidal seagrass meadows with intertidal oyster reefs is the original seascape which had been well-observed in Japan.

Our work is based on an interdisciplinary management approach including i) ecological actions to clarify and ensure the relationship among nutrient loadings, ecosystem functioning which is the processes of matrrial and energy flows with the cycling of nutrients between organic and inorganic forms in the ecosystem (Naeem et al. 1999), and ecosystem services. For example in seagrass beds, nutrient loading sometimes changes the amount of epiphytic production on seagrass leaves which regulate the seagrass growth, resulting in the change of the ecosystem functionings and also in the change of seagrass $\mathrm{CO}_{2}$ sequestration as an ecosystem service, ii) socio-economical actions to estimate both the interface and the pathways between ecosystem services and the recipient human community and also to maintain the sustainable use of ecosystem services, and moreover iii) socio-psychological actions to estimate human well-beings of each stakeholder of the community and also to clarify the key stakeholders responding to the change in the target ecosystem. The ultimate objective of our approach is to identify various ecological and socio-economical management tactics, such as ecological restoration of the coastal environment and economical investment in the oyster aquaculture, and integrate them into an effective management strategy to maximize well-beings of the various stakeholders.This is an essential key to sustain coastal fisheries in areas where water-quality improvement leads to oligotrophication. In particular to harmonize water-quality improvement with seagrass beds and sustainable oyster aquaculture, it is important to demonstrate various effects of seagrass meadows on oyster aquaculture, at least whether the trophic contribution by the increased seagrass bed to oyster aquaculture is significant or not, instead of less amounts of pelagic phytoplankton under oligtrophication.

As a first step of this demonstration in the ecological action using CEC with the eelgrass-oyster interaction, we started a field experiment to clarify the effects of CEC on the trophic aspect of cultured oysters; how the nitrogen and carbon composition of oyster tissues can reflect the change in potential 
food resources under oligotrophication. We analysed the carbon and nitrogen contents of oysters and also the carbon and nitrogen stable isotope concentration to understand the potential contribution of the CEC especially to nitrogen concentration as well as the source of carbons in oyster tissues. This is because the $\mathrm{N}$ and $\mathrm{C}$ contents of bivalves is used to estimate the relationship between bivalve aquaculture and the change in nutrient level, such as eutrophication or oligtrophication in the target ecosystem (Murphy et al. 2016). In this study, we present the preliminary results of the compared N/C ratio, nitrogen contents in molluscous tissues and the carbon and nitrogen stable isotope concentration of oyster spats of three species (Crassostrea gigas, C. nippona and C. sikamea) cultivated using oyster rafts floating on the pelagic ecosystem with other oyster spats cultivated on the tidal flat adjacent to seagrass beds. In the tidal flat, the spats can use several benthic productions as well as pelagic production. The suitable environmental condition would be different among the three oyster species, we tried to identify if some are more suitable for cultivation using CEC.

\section{Materials and Methods}

\section{Conceptual approach}

The Seto Inland Sea (coordinates at its centre : 34.1667 N, $133.3333 \mathrm{E}$ ) is located in the southwestern part of the main island of the Japanese archipelago (Fig. 1a). More than 2000 islands are interspersed in the Seto Inland Sea, so that the complex coast lines form a local seascape which offers calmer areas for oyster raft-aquaculture as well as habitats for eelgrass vegetation by offering protection from heavy winds and wave actions. Offshore oyster aquaculture using natural spats of the native Pacific oyster Crassostrea gigas is flourishing in many areas of the Seto Inland Sea. The annual production in the Seto Inland Sea accounts for more than $60 \%$ of the national production of Japan. Along with oligotrophication, seagrass recovery in the Seto Inland Sea has become apparent in the recent decade because of legal restrictions on 
nutrient input from the watersheds. It has been estimated that the area of seagrass meadows has increased from 6,000 ha to about 10,000 ha in 2011 (hori and Tarutani 2015).

The Thau lagoon (coordinates at its centre : $43.41 \mathrm{~N}, 3.6241 \mathrm{E}$ ) is the largest lagoon located on the southern French coast in the Mediterranean Sea (Fig. 1b). The lagoon is famous for oyster farming using non-native Pacific oyster spats attached on longlines by a specific cement to the spats. The longlines with the spats are hung on oyster tables established in the nearshore zone. About $10 \%$ of the French national production of oysters are cultivated there, the largest oyster farming area in the Mediterranean Sea. It has been suggested that the recovery of seagrass beds is still proceeding, and that now the area of seagrass distribution extends up to 1,000 ha (Hori, personal communication with Syndicat mixte du bassin de Thau). The expansion of eelgrass meadows was observed even within oyster farming areas in June 2016.

As a first step to find harmony between sustainable oyster aquaculture and seagrass conservation under oligotrophication in both the Thau lagoon and the Seto Inland Sea, we devised a management strategy based on an interdisciplinary approach, which consists of ecological, socio-economical and socio-psychological actions. First, the ecological actions aimed to improve or maintain the ecosystem functioning and ecosystem services of a target ecosystem, which consists of two processes : investigations to understand the ecological condition of the ecosystem functioning and the ecosystem services in the target ecosystem, and then management for the sustainable supply of ecosystem serivices based on the knowledge aquired by the investigation. The former investigation includes various ecological research, in particular investigation of the relationship among nutrients, phytoplankton production, seagrass production, oyster production, and the interactions between oyster aquaculture and eelgrass beds.

The socio-economical aspect is important to convey the change of an ecosystem state and ecosystem services to the recipient human community. The socio-economical actions also consist of investigations and management, which are firstly aimed to clarify the commodities and value chains to the human community from oyster and recreational businesses, as well as the interface between ecosystem services 
and socio-economical activities in the target ecosystem. Second, the actions aim to identify the effect of the changes in ecosystem functioning and ecosystem services on the structure of these chains and to draft adaptative tactics for the changes in the target ecosystem. The fundamental purpose of socio-psychological actions was to identify the potential stakeholders and their well-beings in the recipient community, and to influence their view on nature`s values. Some of the ecosystem functioning and services cannot be appreciated based purely on financial aspects, therefore we need to develop a psychological method to directly identify well-being.

\section{First ecological assessment}

As an ecological action to estimate the possibility of oysters can use multiple resources derived from the CEC, we established a field experiment in the Seto Inland Sea to clarify various interactions between oysters and seagrass vegetation. The fundamental motive of this field experiment is also derived from the social unrest in the local community of stakeholders. In both the Seto Inland Sea and the Thau Laoon, it has been a concernof local oyster fishermen and oyster farmers that the decrease of the primary production of the pelagic ecosystem with oligotrophication may cause the decline of oyster production. On the other hand, it is recently suggested that they want to know whether the increased seagrass meadows have any positive and negative effects on oyster production and sustainability in the near future.

In this experiment, we especially analyzed the carbon and nitrogen concentration and the stable isotope ratios of the oyster spats to demonstrate the effect of different food resources on their nutritional condition. The N/C ratio and nitrogen contents of the oyster spats was analyzed to estimate the difference in the change of the nutritional condtion among oyster species. The relationship between carbon and nitrogen stable isotope ratios was examined to know the difference in potential food resources among each oyster species. This difference is derived from the variety of primary productions in both the pelagic 
ecosystem by the raft culture and the benthic ecosystem by the ground culture in the tidal flat. This experiment was conducted at the Oono-Seto channel (Fig. 1c : 34.2747N, 132.2688E), which is also famous for Pacific oyster cultivation in the Seto Inland Sea, Japan. At the site, there is a natural tidal flat adjacent to subtidal seagrass beds. We established an experimental area $(5 \mathrm{~m} \times 5 \mathrm{~m})$ in the lower intertidal area on the tidal flat, and three cages $(50 \mathrm{~cm} \times 50 \mathrm{~cm} \times 10 \mathrm{~cm})$ of five $\mathrm{mm}$ wide mesh were randomly attached on the experimental area (average exposed time of the cages were about 3.0 hour per day) using PVC pipes with iron wire. In addition, we set a raft (5m x 5m) floating on the sea surface $200 \mathrm{~m}$ offshore from the tidal flat, and hung a replicate of three cages at the depth of $2 \mathrm{~m}$ from the sea surface using vinylon ropes.

60 oyster spats of each of three species (C. gigas, C. nippona and C. sikamea), which were hatched from the same lot, were obtained from Shimane prefectual hatchery. 30 spats of each species were put into the cages on the tidal flat, and the other half of spats of each species were put into the cages hanging from the raft. The experiment was conducted for two months from November 2016 to January 2017 when the recruitment of sessile organisms on cages would be lowest (average water tempareture and salinity around the raft during this period was $15.22^{\circ} \mathrm{C}$ and 3.03 , resectively). This was to avoid massive attachments of sessile organisms on the cages, which would make any artifact effects of cage cultivation larger. We randomly chose five spats from each of the six cages at the beginning of the experiment as the initial samples and at the end of the experiment as the samples after two months. After the experiment, the carbon and nitrogen stable isotope analysis was conducted using these samples. In addition, we measured the longest part of the shell length $(\mathrm{mm})$ of all spats at both the beginning and the end of the experiment, and molluscous part weight ratio which was molluscous part weight (gDW) divided by total weight (molluscous and shell weight) of ten spats from each of the six cages at the end of the experiment.

Prior to the stable isotope analysis, specimens of muscle from each oyster spat were taken and dried at $60^{\circ} \mathrm{C}$ for $24 \mathrm{~h}$ and then pulverized. The oyster samples were immersed in a chloroform:methanol (2:1) 

al. 2006). All of the samples were then dried at $60^{\circ} \mathrm{C}$ for $24 \mathrm{~h}$. The dried samples were wrapped in a tin capsule and their carbon and nitrogen stable isotope ratios were measured using a mass spectrometer (ANCA-GSL; Europa Science Inc., UK). Carbon and nitrogen stable isotope ratios were expressed in $\delta$ notation and defined as the per mill deviation from the standard as follows: $\delta 13 \mathrm{C}(\%)$ and $\delta 15 \mathrm{~N}(\%)=$ (R sample/R standard -1$) \times 1000$, where $\mathrm{R}$ is $13 \mathrm{C} / 12 \mathrm{C}$ and $15 \mathrm{~N} / 14 \mathrm{~N}$, respectively. The standard used for the $\delta 13 \mathrm{C}$ and $\delta 15 \mathrm{~N}$ was Vienna Pee Dee Belemnite (VPDB) limestone carbonate and atmospheric nitrogen for $\delta 15 \mathrm{~N}$, respectively. The analytical precision was $0.2 \%$ for $\delta 13 \mathrm{C}$ and $0.3 \%$ for $\delta 15 \mathrm{~N}$.

\section{Results}

241 Our interdisciplinary approach for coastal management under oligotrophic conditions was constructed

242 to be as simple as possible, which consisted of three sections and three actions associated with each

243 section (Fig. 2). As the next step, we have to devise a schematic of ongoing ecological research using an

244 approach clarifying several interactions between oyster farming and seagrass beds to, ultimately, identify better integrated management of ecosystem services in Thau lagoon and the Seto Inland Sea. In particular using structural equation modeling, we will try to identify 1) better management tactics by clarifying the

247 conflicts among ecosystem services, 2) which ecological action is the most important for the development of the human community and environmental conservation, 3) which combination of ecological management tactics and socio-economical management tactics is the most effective to maximize the well-beings of the recipient community, and 4) which is the key pathway from ecosystem services to the 
251 human well-beings via the value chain to improve or maintain both fisheries and the coastal environment

252 under oligotrophic conditions.

Based on this approach, we are now proceeding the research on clarifying the interactions between oyster farming and eelgrass beds to estimate the possibility of oyster farming using seagrass beds as an ecological action in our management (Fig. 3). We have three working hypotheses at the moment : the first is that oyster farming using seagrass beds can maintain or improve coastal productivity including both primary and secondary productions of the target ecosystem even in healthy environmental conditions undergoing oligotrophication. The second hypothesis is that seagrass beds can improve the water quality condition enabling more hygienic cultural practices so that oysters may no longer accumulate pathogens inside them from the ambient seawater. The third hypothesis is that seagrass beds can support oyster production and improve its quality and sustainability. some results which can support the third hypothesis (Fig. 4a-i). There was significant difference in the N/C ratio and nitrogen content of $C$. sikamea between the spats on the tidal flat and those from the offshore raft after two month (Fig. 4c ; one-way ANOVA : $F=20.694, P=0.002$, and Fig. 4f ; one-way ANOVA : $F=8.637, P=0.019$; the assumption of variance homogeneity was kept in each statistical test for the difference in N/C ratio of (c) C. sikamea $(P=0.154)$ and nitrogen cotent of (f) C. sikamea $(P=0.540))$. The average of N/C ratio and nitogen content of both $C$. gigas and $C$. nippona also showed a tendency to be different between the spats on the tidal flat and those from the offshore raft (Fig. 4a and 4b 

may respond to the resources on the tidal flat earlier than other species. the tidal flat and those from the offshore raft in all three species after two months (Fig. 4g-i). The $\delta 13 \mathrm{C}$ of the spats on the tidal flat was around $-17.50 \%$ and was significantly higher than those from the offshore raft, which was around $-19.00 \%$ (Fig. $4 \mathrm{~g}$; one-way ANOVA : $F=23.682, P=0.001$, Fig. 4 h ; one-way ANOVA : $F=98.165, P<0.0001$, Fig. $4 \mathrm{i}$; one-way ANOVA : $F=78.337, P<0.0001$; the assumption of variance homogeneity was also kept in each statistical test for the difference in the carbon stable isotope composition of (g) C. gigas ( $P=0.551)$, (h) C. nippona ( $P=0.731)$, and (i) C. sikamea $(P=0.793)$.). difference between the spats on the tidal flat and those from the offshore raft at the beginning of the experiment, the difference in both $C$. gigas and C. nippona were significant at the end of the experiment (Fig. 5a). The shell length of the spats on the tidal flat was significantly longer than those from the offshore raft (One-way ANOVA ; C. gigas: $F=16.996, P=0.001$, $C$. nippona: $F=17.014, P=0.001$ ), while the shell length of the $C$. sikamea spats did not significantly differ between the tidal flat and the offshore raft. However, the molluscous weight ratio exhibited the opposite tendency of the shell growth (Fig. 5b) ; the molluscous weight ratio of the spats on the tidal flat was higher than those from the offshore raft.

287 There was a significant difference in the molluscous weight ratio of the $C$. nippona and $C$ sikamea spats between the tidal flat and the offshore raft (One-way ANOVA ; C. nippona: $F=6.669, P=0.0019, C$. 


\section{Discussion}

292

Among our working hypotheses at the moment, the first hypothesis is derived from a well-known

function of seagrass beds called trophic support (Williams and Heck 2001). To our knowledge, however,

295

there is no case study directly demonstrating the effects of oyster-seagrass interactions on ecosystem

functioning of target ecosystems, although there are some modelling researches on the material cycling in

297

a coastal ecosystems including oyster and seagrass beds (Kishi and Oshima 2008). Further studies are

298

needed to demonstrate this hypothesis. The second hypothesis requires the study of the effects of the

299

change in environmental conditions by seagrass beds on the quality of oysters, which will potentially

300

enhance the value of oyster products. Actually in other regions, it was reported that there was a $50 \%$

301

reduction in the relative abundance of potential bacterial pathogens capable of causing disease in humans

302

and marine organisms when seagrass beds are present (Lamb et al. 2017).

303

The third hypothesis requires the study of the trophic effects of the change in the potential food

304

resources induced by seagrass beds on oyster production, as a dominant ecosystem service in our study

305

sites. The results of our ongoing experiment suggest that the spats on the tidal flat contained a higher

nitrogen concentration in their muscle than those from the offshore raft even in this period when benthic

production is lower than pelagic production in this region (Uye and Shimazu 1997 ; Sarker et al. 2009),

and moreover that the $\delta 13 \mathrm{C}$ of the spats on the tidal flat was significantly higher than those from the

offshore raft. This was presumably because the oyster spats from the offshore rafts used only pelagic 
production (pelagic POM: -22.00 +/-0.14 \%o, Hamaoka, unpubl. data, 2017 ; the POM was collected by

311 filteration of surface seawater in this study site) while the oyster spats on the tidal flat can use both

312 pelagic and benthic production (Benthic POM on tidal flat: $-17.00+/-0.57$ \%, seagrass :

$313-10.50+/-0.71 \%$ o, Hamaoka unpubl. Data, 2017 ; the POM was collected from the surface of rocks on the

314 tidal flat and also collected on the seagrass leaves). These results suggest that utilization of benthic

315 production can increase the nitrogen content of cultivated oysters, meaning a change in the quality as a

316 food provisioning service for human beings.

317 In addition, research on the stable isotope analysis for cultivated oysters in the Thau lagoon also

318 exhibited a result that can support the third hypothesis (Fig. 6). The $\delta 13 \mathrm{C}$ of cultivated oysters seasonally

319 varied with their food resources, which would depend on organic carbon derived from benthic organic

320 carbon through pelagic organic carbon (Pernet et al. 2012). These trophic interactions demonstrated in

321 both our ongoing experiment and Thau lagoon are not only a phenomenon in the eelgrass and Pacific

322 oyster interaction, but are also reported as the interactions between seagrasses and filter-feeding bivalves

323 in various seagrass meadows from temperate to tropical regions of the world (Morimoto et al. 2017).

324 There are many reports of the contribution of eelgrass beds consisting of Zostera species and the

325 associated epiphytes as a potential food resource for various bialves species (e.g., in Russia: Kharlamenko

326 et al. 2001, Germany: Jaschinski et al. 2008, Portugal : Rossi and Marques 2015), and France : Lebreton

327 et al. 2011). These studies suggest a general occurrence of the trophic interactions between filter-feeding bivalves and seagrasses. 
Pacific oyster would be common and an important component of the ecosystem functioning in coastal

331

332

333 indicating that Pacific oysters imported from Japan can grow even in the oligotrophic environment ecosystems, because Pacific oyster reefs had often been found adjacent to seagrass beds. Unfortunately, the natural mixed-landscape of oyster reefs with seagrass beds has been lost due to coastal development by reclamation and construction of embankments in many regions of Japan. In some regions, however, aquaculture areas have been established within or adjacent to seagrass beds (Kasim and Mukai 2006 ; Tanaka 2014). The oysters have been grown using the original oyster-seagrass interactions including facilitation of spat recruitment and spat survival rate, and especially trophic support from eelgrass beds to oysters over an extended period of time [32]. This is typically reflected in indigenous and local knowledge (ILK) of Japanese oyster aquaculture.

One of our interests in this research is also whether these oyster-eelgrass interactions in the original habitats of Japan has appeared in the Thau lagoon ecosystem with native eelgrass beds and non-native Pacific oysters, and whether the oyster-eelgrass interactions can also facilitate ecosystem functioning outside of its native range. Pernet et al. (2012) revealed by the analysis of both carbon isotope ratio and fatty acid signatures that the food resources of Pacific oysters seasonally varied among phytoplankton, diatoms, bacteria and terrestrial organic matter in the Thau lagoon. This result suggests that oysters in the Thau lagoon have a potential to consume various kinds of food resources derived from different origins, effectively utilizing multiple habitats in the French coastal zone. In the future, we need to proceed with 

pathogen and toxification.

351 In oligotrophic environmental conditions, our first ecological action aims to increase coastal 352 productivity not by increasing the nutrient level, but by facilitating various benthic productions including seagrass beds. Interactive resource subsidies between eelgrass and oysters can supply epiphytes and detritus as food resources for oysters, and nutrients and POM as resources for eelgrass and the eelgrass-associated organisms. Seagrass-oyster interactions would become a key factor to improve bio-resource cycling and thus the ecosystem functioning efficientlty in the study area. If the above three hypotheses are successfully verified, the recipient human community in the socio-economical section of our approach can gain valuable products and a better environment (Fig. 3). The change in the ecosystem services and the recipient community by the ripple effect of ecological action would cause the change in well-beings of the stakeholders in the target ecosystem. conditions, which is also beneficial for recreational use. Larger distribution of eelgrass beds can absorb more carbon dioxide from the atmosphere and store them as organic carbon, which can offset the carbon emissions from oyster aquaculture and recreational activities. This kind of local offset system of carbon dioxide emission can contribute to the promotion of the Paris Agreement adopted at UNFCC-COP21. Our study has just been initiated, so we have to make steady progress associated with the CEC concept to identify wise-use and better management for oligotrophic coastal ecosystems through these ecological, 
371 Acknowledgement. We would like to thank our French colleague, Yves Henocque for his various

372 suggestions and immemse help. This research could not have progressed without his considerable support.

373 We are also grateful to the Japanese-French Oceanographic Society for offering this opportunity to

374 present our research. We also thank C. J. Bayne for checking the English text. This study is supported by

375 several fundings including the FRA and Ifremer, by the Environment Research and Technology

376 Development Fund (S-15) of the Ministry of the Environment, Japan, and by JSPS SAKURA program

377 (No. 17031011-000161).

378

379 
Arkema KK, Guannel G, Verutes G, Wood SA, Guerry, Ruckelshaus AM, Kareiva P, Lacayo M, Silver JM (2013) Coastal habitats shield people and property from sea-level rise and storms. Nat Climate Change 3: 913-918

Arrington DA, Davidson BK, Winemiller KO, Layman CA (2006) Influence of history and seasonal

IPCC (2007) Climate Change 2007: Impact, adaptation and vulnerability. Contribution of working group 400 hydrogy on lipid storage in three neotropical fish species. J Fish Biol 68: 1347-1361

Burkholder JM, Tomasko DA, Touchette BW (2007) Seagrasses and eutrophicaton. J Exp Mar Biol Ecol 350: $46-72$

Collos Y, Bec B, Jauzein C, Abadie E, Laugier T, Lautier J, Pastoureaud A, Souchu P, Vaquer A (2009) Oligotrophication and emergence of picocyanobacteria and a toxic dinoflagellate in Thau Lagoon, southern France. J Sea Res 61: 68-75

Duarte CM, Losada IJ, Hendriks IE, Mazarrasa I, Marba N (2013) The role of coastal plant communities for climate change mitigation and adaptation. Nat Climate Change 3: 961-968

Hori M, Kuwae T (2017) Blue carbon: hidden processes for CO2 uptake and carbon storage in shallow water ecosystems, policy and implementation. Chijin Shokan press, Tokyo (in Japanese)

Hori M, Tarutani K (2015) Changes in the distribution of seagrass vegetation with relation to the possible regime shift from pelagic-dominant to benthic-dominant system in Seto Inland Sea. In: Yamamoto T, Hanazato T (eds) Issues of oligotrophication in ocean and lakes. Chijinshokan press, Tokyo, pp 129-148 (in Japanese) II to the fourth assessment. In: Parry ML et al (eds) Report of the Intergovernmental Panel on Climate Change. Cambridge University Press, Cambridge, 976 pp 
Jaschinski S, Brephohi DC, Sommer U (2008) Carbon sources and trophic structure in an eelgrass Zostera marina bed, based on stable isotope and fatty acid analyses. Mar Ecol Prog Ser 358: 103-114

Kasim M, Mukai H (2006) Contribution of benthic and epiphytic diatoms to clam and oyster production in the Akkeshi-ko estuary. J Oceanogr 62: 267-281

Kharlamenko VI, Kiyashko SI, Imbs AB, Vyshkvartzev DI (2001) Identification of food resources of invertebrates from the seagrass Zostera marina community using carbon and sulfur stable isotope ratio and fatty acid analyses. Mar Ecol Prog Ser 220: 103-117

Kishi MJ, Oshima Y (2008) The role of benthos and epiphyte on the material cycle in Akkeshi lake, Japan. In: Mohanty PK (ed) Monitoring and Modeling Lakes and Coastal Environments. Springer, Netherlands, pp 151-158

Lamb JB, van de Water JAJM, Bourne DG, Altier C, Hein MY, Florenze EA, Abu N, Jompa J, Harvell CD (2017) Seagrass ecosystems reduce exposure to bacterial pathogens of humans, fishes, and invertebrates. Science 355: 731-733

Lebreton B, Richard P, Galois R, Radenac G, Pfleger C, Guillou G, Mornet F, Blanchard GF (2011) Trophic importance of diatoms in an intertidal Zostera noltii seagrass bed: Evidence from stable isotope and fatty acid analyses. Estuar Coast Shelf Sci 92: 140-153

Matsuda O (2015) Towards rich Seto Inland Sea, considerable change of the basic plan on Seto Inland Sea approved by the cabinet. Yutakana Umi 36: 7-12 (in Japanese)

Morimoto N, Umezawa Y, San Diego-Mcglone ML, Watanabe A, Siringan EP, Tanaka Y, Regino GL, Miyajima T (2017) Spatial dietary shift in bivalves from mbayment with river discharge and mariculture activities to outer seagrass beds in northwestern Philippines. Mar Biol 164: 84. doi:10.1007/s00227-016-3063-z 
Murphy AE, Emery KA, Anderson IC, Pace ML, Brush MJ, Rheuban JE (2016) quantifying the effects of commercial clam aquaculture on $\mathrm{C}$ and $\mathrm{N}$ cycling: an integrated ecosystem approach. Estuar Coast 39: $1746-1761$

Naeem S, Chapin FS III, Costanza R, Ehrlich PR, Golley FB, Hooper DU, Lawton JH, O’Neill RV, Mooney HA, Sala OE, Symstad J, Tilman D (1999) Biodiversity and Ecosystem functioning: maintaing natural life support processes. Issues in Ecology \#4, Ecological Society of America, Wahington DC

Odling-smee FJ, Laland KN, Feldman MW (2003) Niche construction: the neglected process in evolution. Princeton University Press, Oxford

Pernet F, Malet N, Pastoureaud A, Vaquer A, Quere C, Dubroca L (2012) Marine diatoms sustain growth of bivalves in a Mediterranean lagoon. J Sea Res 68: 20-32

Pittman S, Kneib R, Simenstad C, Nagelkerken I (2011) Seascape ecology: application of landscape ecology to the marine environment. Mar Ecol Prog Ser 427: 187-19

Post JR, Parkinson EA (2001) Energy allocation strategy in young fish: allometry and survival. Ecology 82: $1040-1051$

Rossi F, Baeta A, Marques JC (2015) Stable isotopes reveal habitat-related diet shifts in facultative deposit-feeders. J Sea Res 95: 172-179

Sarker MDJ, Yamamoto T, Hashimoto T (2009) Contribution of benthic microalgae to the whole water algal biomass and primary production in Suo Nada, the Seto Inland Sea, Japan. J Oceanogr 65: 311-323

Scheffer M, Carpenter S, Foley JA, Folke C, Walker B (2001) Catastrophic shifts in ecosystems. Nature 413: 591-596 
446

447

448

449

450

451

452

453

454

455

456

457

458

459

460

461

462

463

464

465

466

467

Selman M, Greenhalgh S (2009) Eutrophication: policies, actions, and strategies to address nutrient pollution. WRI Policy Note 3: 1-16

Tanaka T (2014) Satoumi with eelgrass and oyster beds, ‘Hinasesengen-ryoshimachi’ (Hinase, Okayama). Nippon Suisan Gakkaishi 80: $72-75$ (in Japanese)

Tsurita I, M. Hori M, Makino M (2017) Fishermen and conservation: sharing the case study of Hinase, Japan. In Westlund L et al (eds) FAO-FA Technical Paper 603: Marine Protected Areas : Interactions with Fishery Livelihoods and Food Security, FAO, Rome, pp. 43-50

Uye S, Shimazu T (1997) Geographical and seasonal variation in abundance, biomass and estimated production rates of meso- and macrozooplankton in the Inland Sea of Japan. J Oceanogr 53: $529-538$

Williams SL, Heck KL Jr (2001) Seagrass community ecology. In: Bertness MD, Gaines SD, Hay ME (eds) Marine community ecology. Sinauer Associates, Massachusetts, pp 317-338

Yamamoto T, Hanazato T (2015) Issues of oligotrophication in ocean and lakes. Chijinshokan, Tokyo (in Japanese)

Yanagi T (2015) Eutrophication and oligotrophication in Japanese estuaries: the present status and future tasks. Springer, Dorderecht

(1) 
469

Fig. 1 Study sites of this research, (a) the Seto Inland Sea in Japan, (b) Thau lagoon in France, and (c)the location where the experiment was conducted in Seto Inland Sea (dark shaded area : tidal flat, black colored area : eelgarass beds, opened squre : oyster raft, and opened circle : the site where the cages were set)

Fig. 2 Schematic explanation of the approach adopted in this study.

Fig. 3 The possible pathway that the oyster-seagrass interaction as an ecological action positively influence the recipient community via the change in the ecosystem functioning and ecosystem services.

Fig. 4 The comparisons of N/C weight ratio, nitrogen content, and carbon and nitrogen stable isotope composition between raft (open circles) and tidal flat (closed circles) cultured three oyster species (C. gigas, C. nippona and C. sikamea). Open squares indicate initial conditions. Significant $p$-values are represented by asterisks: ${ }^{*} p<0.05$; ${ }^{* *} p<0.01$; ${ }^{* * *} p<0.001$.

Fig. 5 The difference in (a) the longest part of shell length and (b) molluscous part ratio of each oyster species between the spats cultivated on the tidal flat and those from the offshore raft. Significant $p$-values are represented by asterisks: ${ }^{*} p<0.05 ;{ }^{* *} p<0.01 ;{ }^{* * *} p<0.001$. 
489 Fig. 6 The relationship of carbon stable isotope composition among Pacific oyster, river-derived POM, marine-derived POM, biofilm, benthic POM and seagrass in Thau Lagoon. The numerical values exhibited as shaded circles and a solid arrow were from the data in Pernet et al. (2012) and as open circles were our unpublished data, respectively. The solid arrow shows the range of the annual change in the carbon stable isotope value of pacific oyster. Benthic POM were collected on seagrass leaves and small rocks in seagrass beds.

495 


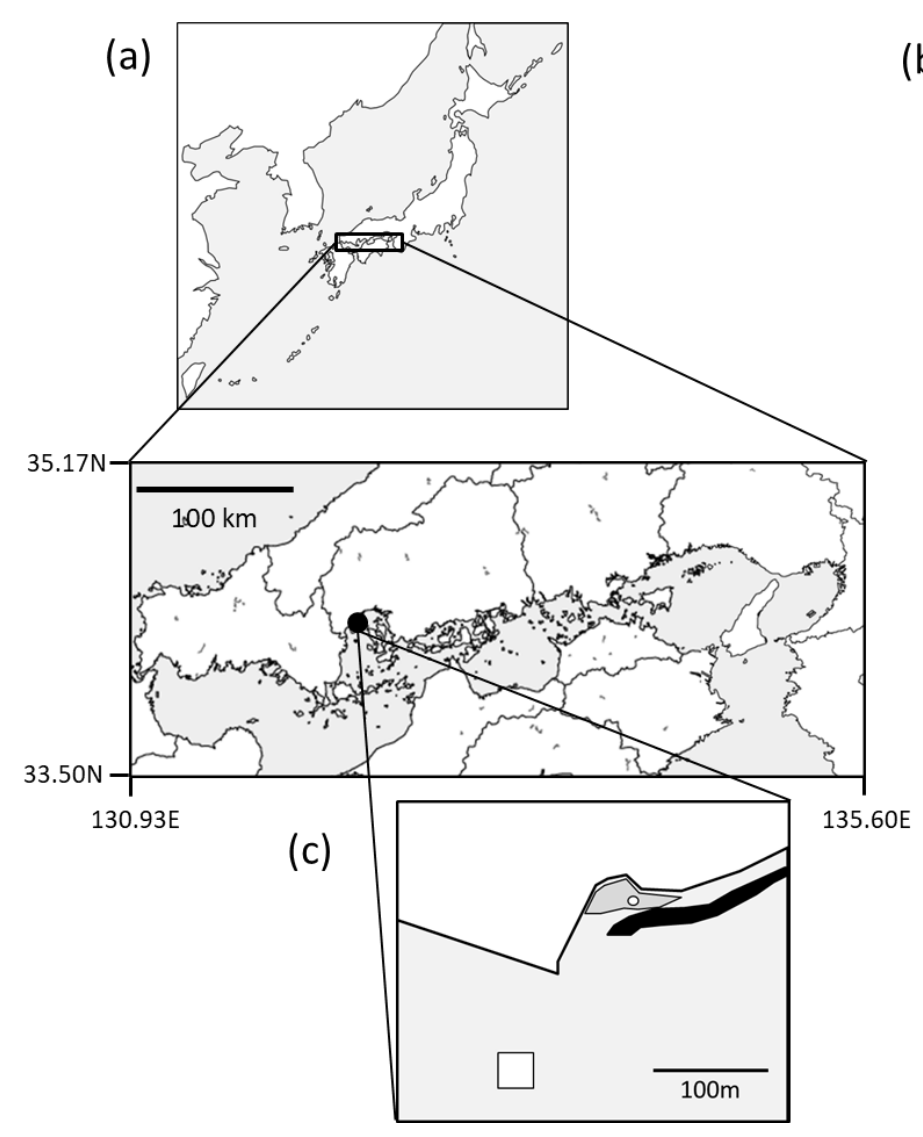

(b)

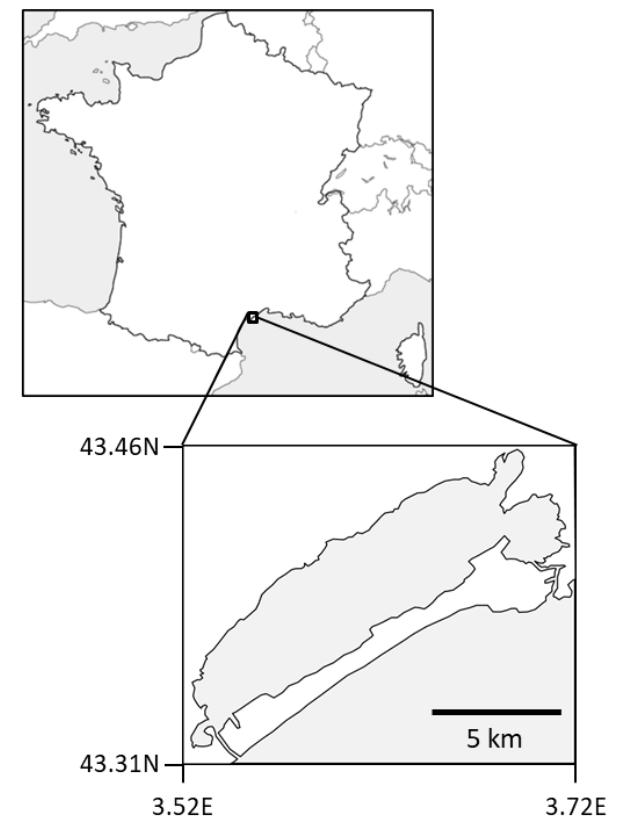

Fig. 1 
Reaction/feedback by economical processes or governance

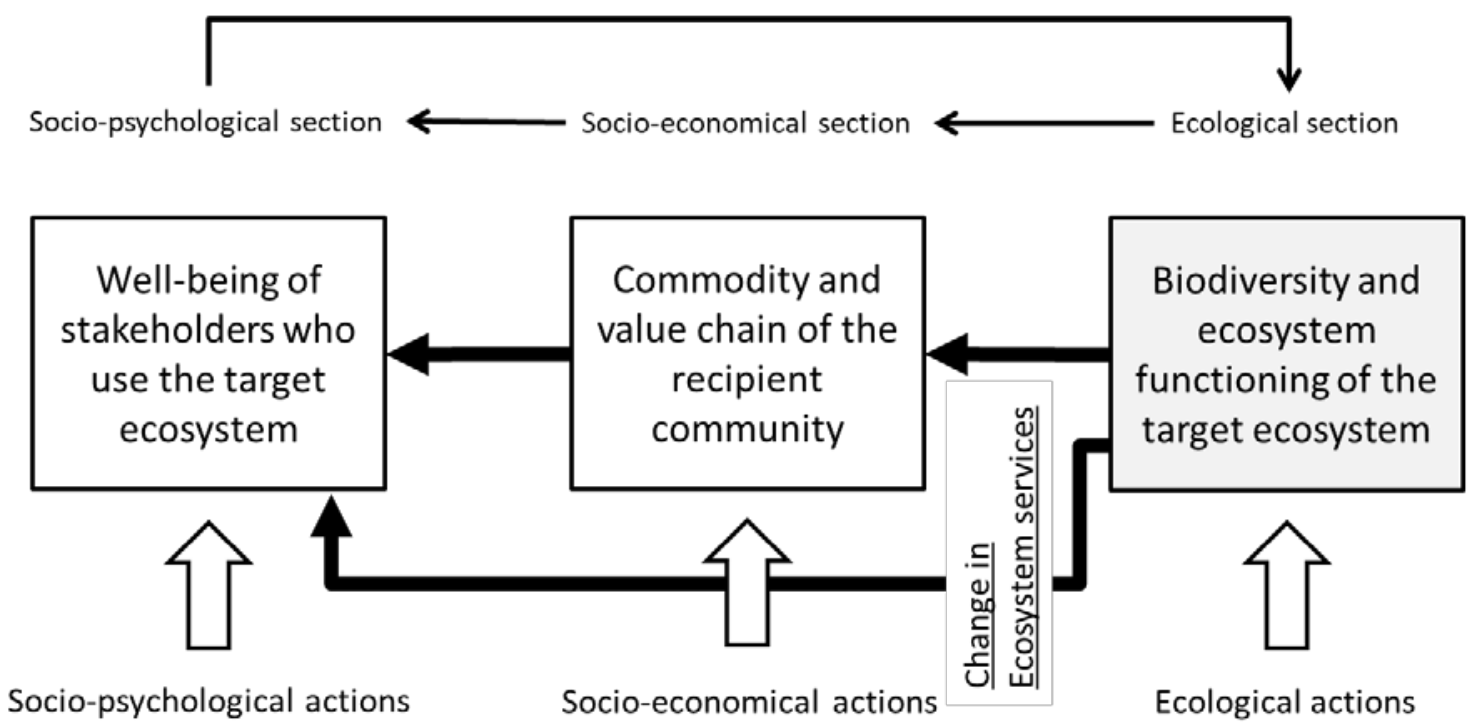

Fig. 2 


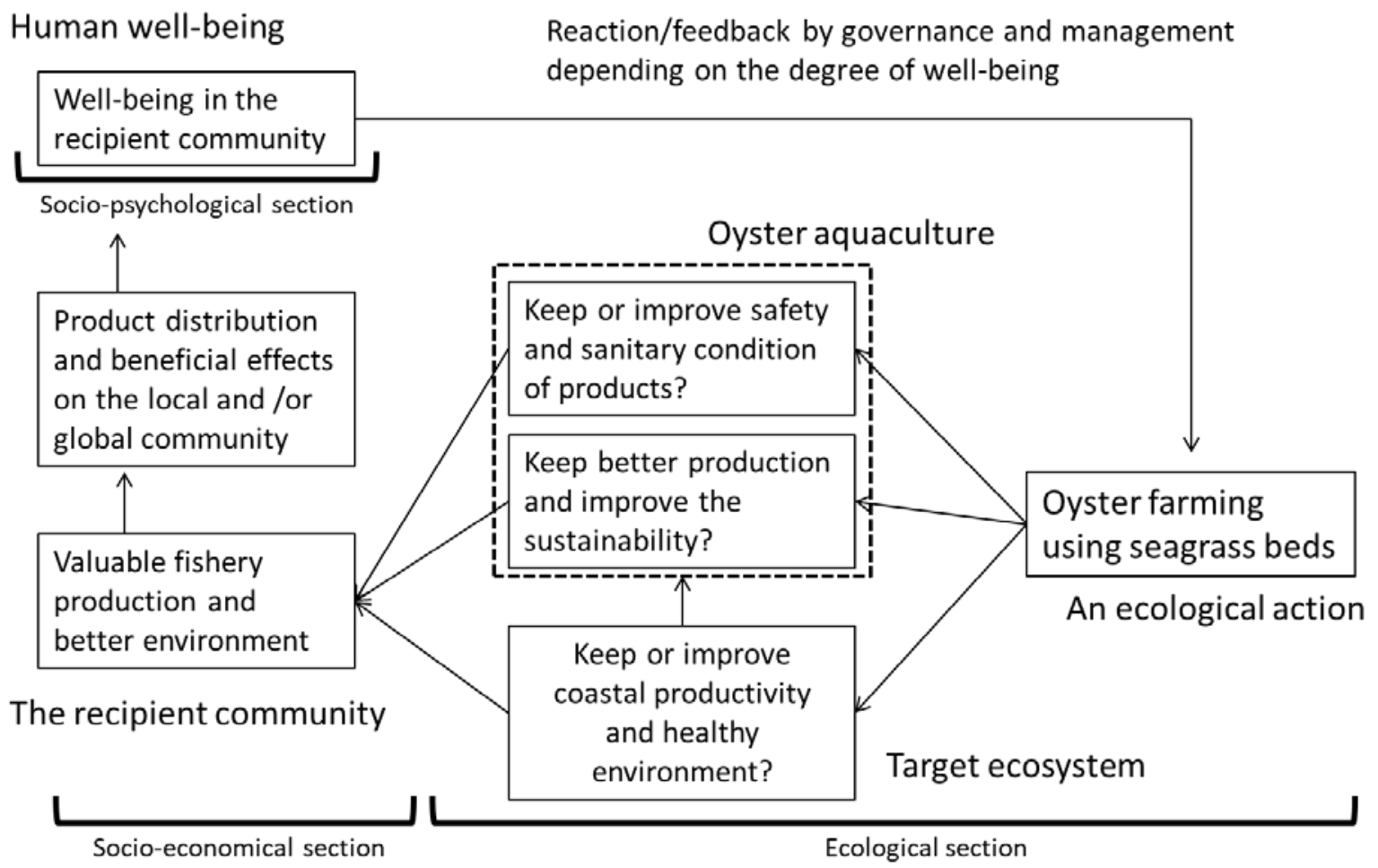

Fig. 3 


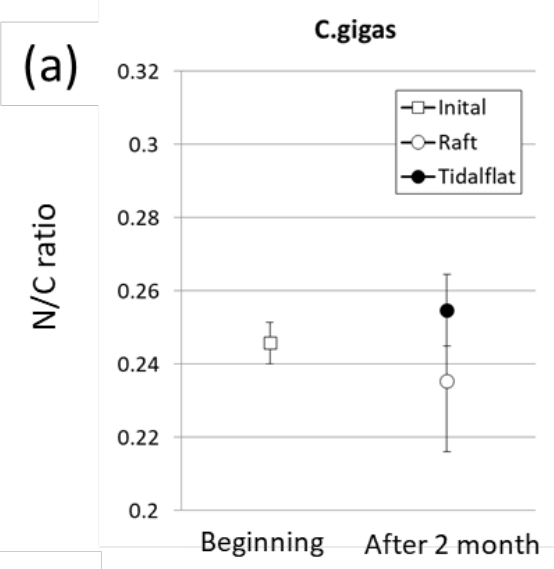

(d)
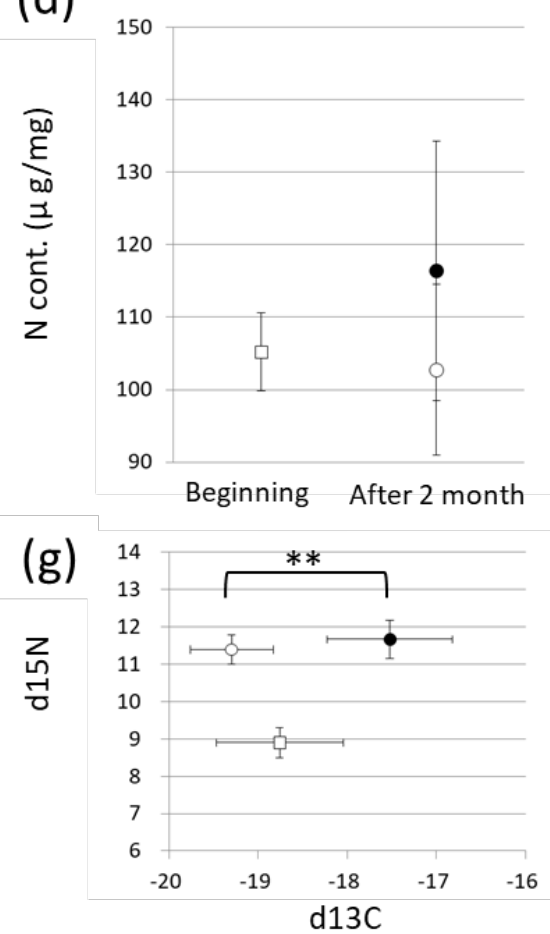

(b)

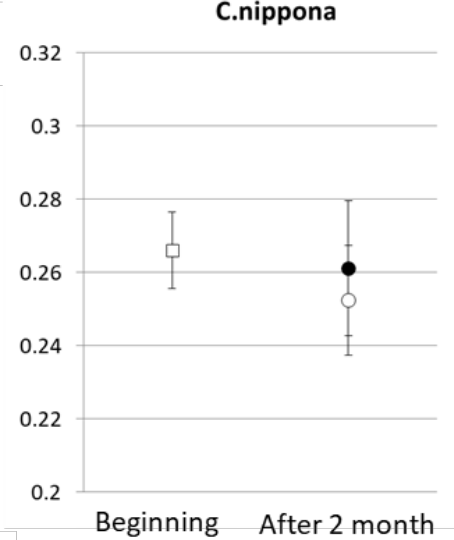

(e)

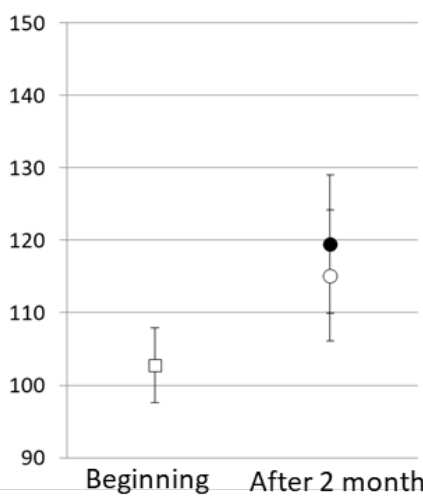

(h)

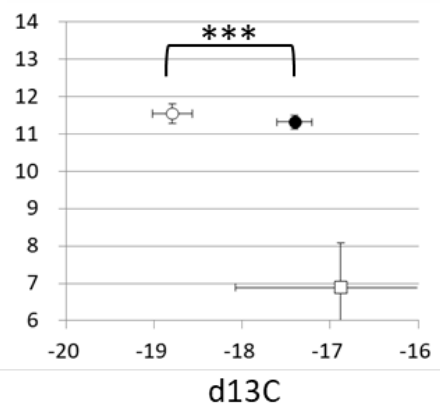

(c)

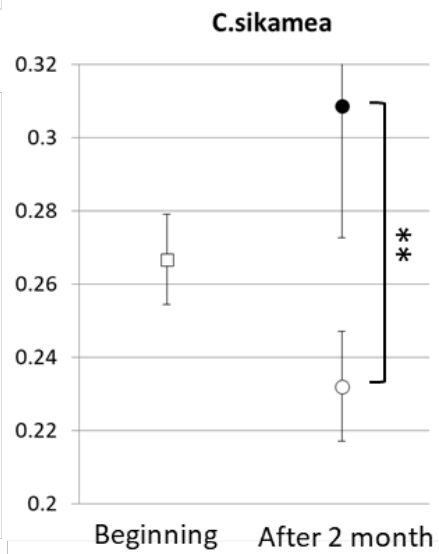

(f)

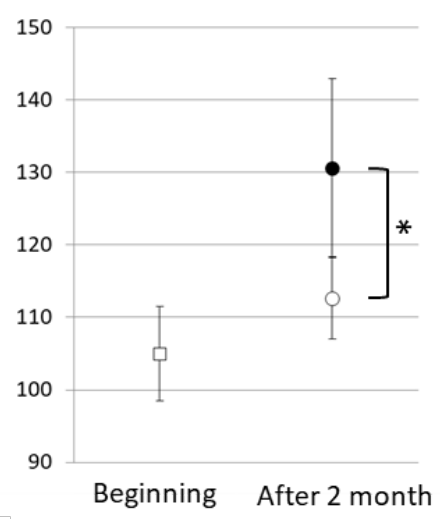

(i)

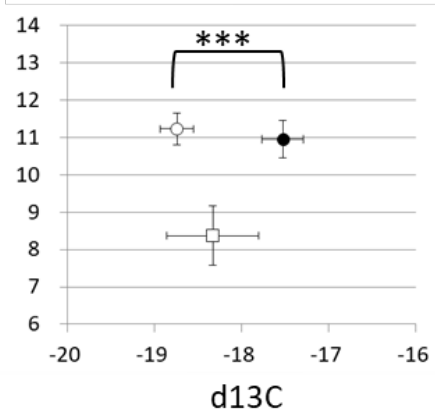

Fig.4 
(a)

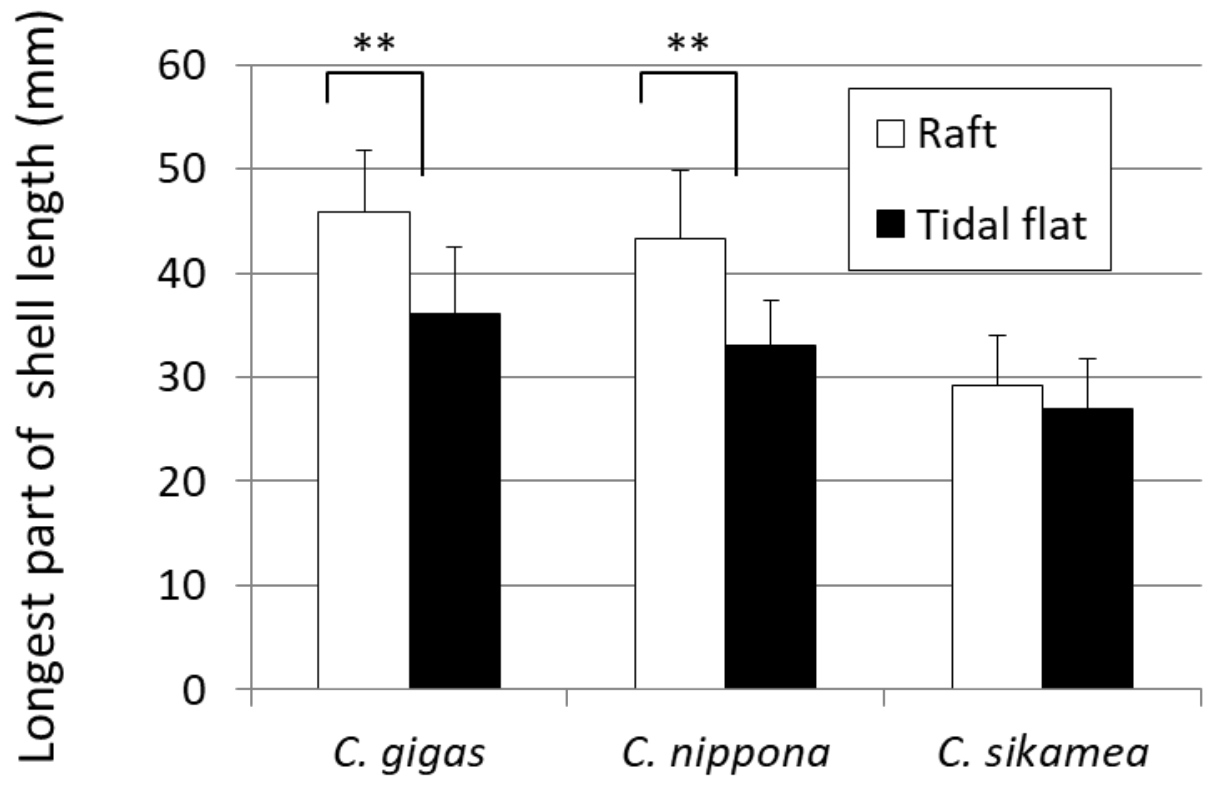

(b)

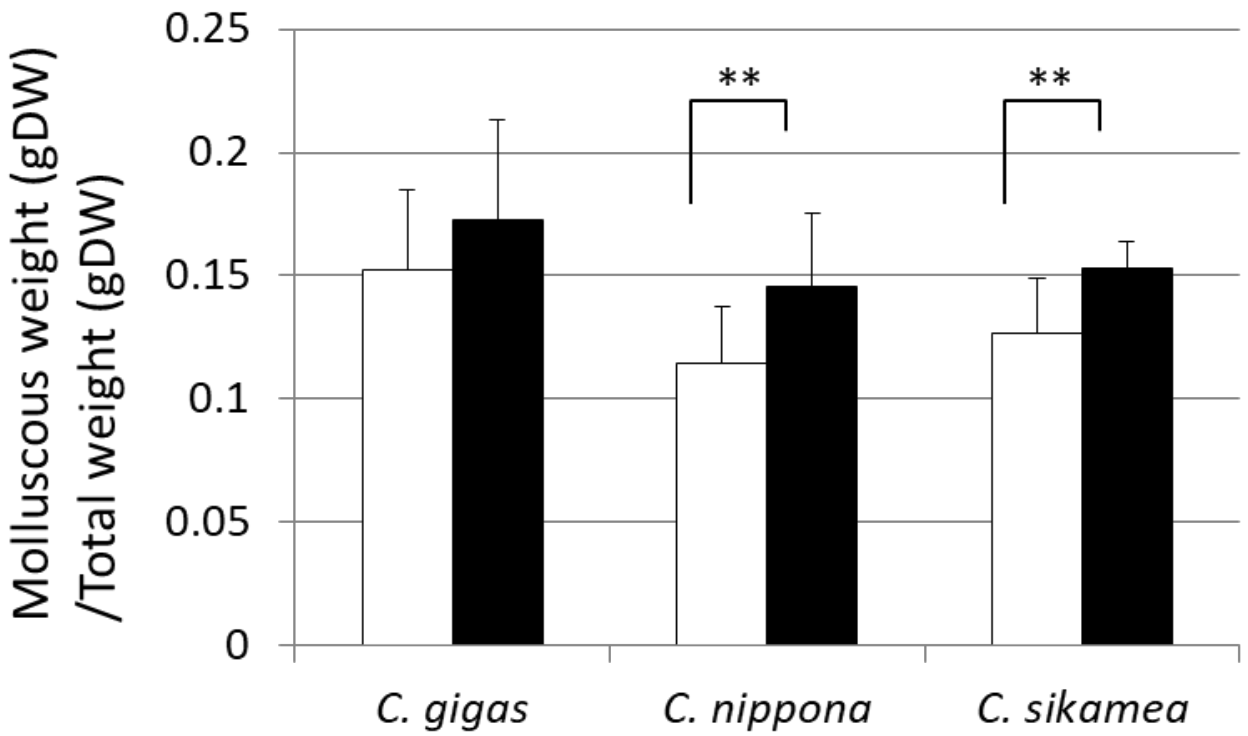

Fig. 5 


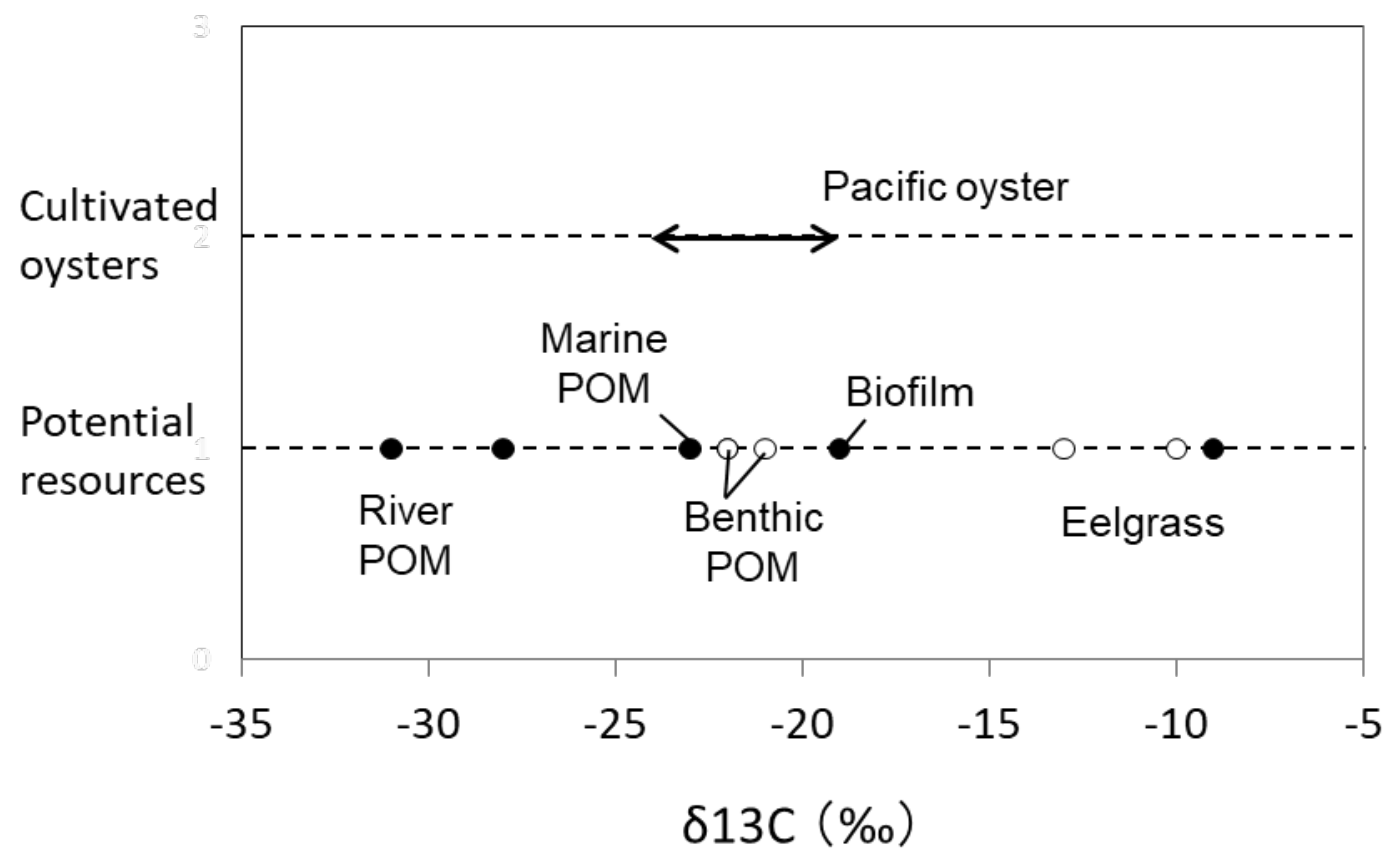

Fi.g 6 